\title{
Minding the gap between theory and clinical practice: an individualised approach to the management of feline diabetes mellitus
}

\author{
Moira S Lewitt ${ }^{1}$, Emma Strage ${ }^{2^{*}}$, David Church $^{3}$ \\ From Animal Obesity - causes, consequences and comparative aspects \\ Uppsala, Sweden. 14-16 June 2015
}

\begin{abstract}
Introduction
Insulin independence is a realistic therapeutic goal in feline diabetes. Remission is dependent on achieving fast glycemic control. However, without intensive monitoring high insulin doses increase the risk of hypoglycemia. An 11-year old spayed Burmese cat presented with diabetes after steroid treatment for skin allergy. Control of blood glucose was not achieved using low carbohydrate diet plus the recommended $\mathrm{q} 12 \mathrm{~h}$ treatment with either insulin lente or glargine, with the total dose limited by the risk of hypoglycaemia.
\end{abstract}

\section{Objectives}

The aim was to achieve euglycaemia and insulinindependence.

\section{Methods}

A more frequent insulin treatment was tried. Seven weeks from start of $\mathrm{q} 12 \mathrm{~h}$ treatment, the total daily dose of insulin glargine was divided across three injections. One week later the frequency of injection was increased to q6h. There was intensive monitoring of capillary blood glucose (Accu-Chek Aviva).

\section{Results}

There was a prominent glucose nadir after approximately 4h regardless of insulin type. Within four weeks on insulin q8h and q6h blood glucose levels were within the normal range. Weight gain was noted and within one week of caloric restriction insulin was withdrawn completely. One month later fructosamine had normalized and after

\footnotetext{
* Correspondence: emma.strage@slu.se

${ }^{2}$ Department of Clinical Sciences, Swedish University of Agricultural Sciences, Uppsala, Sweden

Full list of author information is available at the end of the article
}

more than three years the cat remains off insulin with blood glucose levels at the upper limit of the reference range.

\section{Conclusions}

More frequent insulin injections than recommended in literature may be necessary to achieve glycemic control. Owners are important collaborators in feline diabetes care and with intensive home monitoring more frequent insulin treatment may lead to remission without hypoglycemia.

\section{Authors' details}

${ }^{1}$ School of Health, Nursing and Midwifery, University of the West of Scotland, Paisley, UK. ²Department of Clinical Sciences, Swedish University of Agricultural Sciences, Uppsala, Sweden. ${ }^{3}$ Department of Veterinary Clinical Sciences, Royal Veterinary College, University of London, London, UK.

Published: 25 September 2015

doi:10.1186/1751-0147-57-S1-P57

Cite this article as: Lewitt et al:: Minding the gap between theory and clinical practice: an individualised approach to the management of feline diabetes mellitus. Acta Veterinaria Scandinavica 2015 57(Suppl 1):P6.

Submit your next manuscript to BioMed Central and take full advantage of:

- Convenient online submission

- Thorough peer review

- No space constraints or color figure charges

- Immediate publication on acceptance

- Inclusion in PubMed, CAS, Scopus and Google Scholar

- Research which is freely available for redistribution

Submit your manuscript at www.biomedcentral.com/submit
() Biomed Central 